\title{
CLINICAL UTILITY OF TWO LEUKOCYTE ESTERASE REAGENT STRIPS FOR THE COW-SIDE DIAGNOSIS OF SUBCLINICAL MASTITIS IN LACTATING DAIRY CATTLE
}

\author{
SAHAR A. KANDEEL ${ }^{1,2} ;$ MOHAMED H.EBIED $^{1}$; FAYSAL K. ARNAOUT ${ }^{1}$; \\ ELSAYED M. GALILA ${ }^{1}$; AMEER A. MEGAHED ${ }^{1,2}$ and PETER D. CONSTABLE ${ }^{2}$ \\ ${ }^{1}$ Department of Animal Medicine, Faculty of Veterinary Medicine, Benha University, Kalyobiya, 13736, Egypt \\ ${ }^{2}$ Department of Veterinary Clinical Medicine, College of Veterinary Medicine, University of Illinois \\ at Urbana-Champaign, Illinois, 61802, USA
}

Received: 21 Augusts 2017; $\quad$ Accepted: 25 September 2017

\begin{abstract}
Mastitis increases the activity of more than 20 enzymes in the glandular secretions of dairy cattle, including esterase. We hypothesized that milk esterase activity provides an inexpensive, rapid, and practical cow-side method for diagnosing subclinical mastitis (SCM). Our objective was therefore to determine the clinical utility of measuring esterase activity in quarter milk samples using Multistix ${ }^{\circledR}$ and PeriScreen ${ }^{\mathrm{TM}}$ strips to predict SCM. Quarter foremilk samples were collected from 115 dairy cows at dry-off and 92 fresh cows within 4-7 days post calving. Quarter somatic cell count (SCC) was measured using Delaval ${ }^{\circledR}$ cell counter with $\mathrm{SCC} \geq 200,000$ cells $/ \mathrm{mL}$ as the reference method for diagnosing SCM. Milk esterase activity was measured using Multistix ${ }^{\circledR}$ and PeriScreen $^{\mathrm{TM}}$ strips. The area under the receiver operating curve (AUC), kappa coefficient $(\kappa)$, and positive likelihood ratio $(+\mathrm{LR})$ were calculated and $\mathrm{P}<0.05$ was considered significant. The Serim PeriScreen ${ }^{\mathrm{TM}}$ strips had a marginally better diagnostic performance than the Multistix ${ }^{\circledR}$ strips. At the optimal cut-point $>$ trace, the PeriScreen $^{\mathrm{TM}}$ strip had an $\mathrm{AUC}=0.75, \kappa=0.32$, and $+\mathrm{LR}=25.5$ at dry-off, and $\mathrm{AUC}=0.66, \kappa=0.38$, and $+\mathrm{LR}=\infty$ in fresh cows. At the optimal cut-point $\geq$ trace, the Multistix ${ }^{\circledR}$ strip had an AUC=0.71, $\kappa=0.31$, and $+\mathrm{LR}=4.2$ at dryoff, and $\mathrm{AUC}=0.63, \kappa=0.31$, and $+\mathrm{LR}=14.0$ in fresh cows. The AUC, $\kappa$, and $+\mathrm{LR}$ values for the Multistix ${ }^{\circledR}$ and PeriScreen $^{\mathrm{TM}}$ strips are considered suboptimal for a diagnostic test because clinically useful tests typically have an AUC $>0.80, \kappa>0.6$, or $+\mathrm{LR}>10$. We therefore conclude that Multistix ${ }^{\circledR}$ and PeriScreen ${ }^{\mathrm{TM}}$ strips do not provide clinically useful cow-side tests for diagnosing SCM in lactating dairy cattle.
\end{abstract}

\section{List of abbreviations:}

SCC: Somatic cell count; IMI: Intramammary infection; SCM: Subclinical mastitis; PMNs: Polymorphonuclear cells; DCC: Delaval ${ }^{\circledR}$ cell counter; AUC: Area under the curve; ROC: Receiver operating characteristic curve; Se: Sensitivity; Sp: Specificity; K: kappa coefficient

Key words: Intramammary infection, Somatic cell count, Serim PeriScreen ${ }^{\mathrm{TM}}$ strips, Multistix ${ }^{\circledR}$ strips, Delaval $^{\circledR}$ cell counter.

\section{INTRODUCTION}

Mastitis leads to a variety of compositional changes in milk due to local inflammation, damage to glandular tissue, increased leukocyte counts, and serum components entering the milk due to increased permeability of the blood-milk barrier (Kitchen, 1981; Pyörälä, 2003). As a result, mastitis is accompanied by change in the level of at least 20 enzymes in glandular secretions (Kitchen, 1981).

Corresponding author: Dr. Sahar A. Kandeel

E-mail address: skandeel@illinois.edu

Present address: Department of Animal Medicine, Faculty of Veterinary Medicine, Benha University, Kalyobiya, 13736, Egypt and Department of Veterinary Clinical Medicine, College of Veterinary Medicine, University of Illinois at Urbana-Champaign, Illinois, 61802, USA
These enzymes include N-acetyl-D-glucosaminidase (NAG'ase), beta-glucuronidase, lactate dehydrogenase, alkaline phosphatase, aspartate aminotransferase, plasmin, catalase, elastase, and esterase (Kitchen, 1981; Zhao and Lacasse, 2008). Measurement of milk enzyme activity therefore has potential as a screening test for subclinical mastitis (SCM; Viguier et al., 2009).

Esterase is primarily found in leukocytes, especially granulocytes (neutrophils, eosinophis, basophils) and the azurophilic granules of monocytes. Esterase enzymatic activity is the basis of the leukocyte esterase reagent strips that have been developed and produced by several manufacturers and marketed under different commercial names worldwide to detect leukocytes in a variety of body fluids. The 
Leukocyte esterase reagent strips were developed initially as a semi-quantitative test for leukocytes in urine (St. John et al., 2006), and have been shown to be useful in other body fluids suc has peritoneal (Koulaouzidis et al., 2008), synovial (McNabb et al., 2017), cerebrospinal (Moosaet al., 1995) and bronchoalveolar lavage fluid (Jacobs et al., 2000) for detecting the presence of increased numbers of leukocytes (Mendler et al., 2010). The World Health Organization has published guidelines for the development of diagnostic tests for infectious agents in resource-poor settings. The tests must be affordable, sensitive, specific, user-friendly, rapid and robust, equipment free, and delivered to those in need, providing the acronym "ASSURED" (Urdea et al., 2006; Yetisen et al., 2013). The esterase reagent strip has several advantages over other point-of care tests including ease of use, low cost, and short test time.

The Multistix $^{\circledR}$ urine test strip pad contains a detergent and 3-hydroxy-5-phenyl-pyrole esterified with an amino acid that is used as an enzyme substrate (Mendler et al., 2010). The detergent lyzes granulocytes, predominantly neutrophils, that have been absorbed into the pad and releases esterase that hydrolyses the ester compound, thereby releasing a pyrole compound that reacts with a diazonium salt to yield a violet/purple azo dye. The intensity of the violet color is correlated with the leukocyte count (Kutter et al., 1987; Moosa et al., 1995). The Peri Screen $^{\mathrm{TM}}$ test strip is designed to provide a semiquantitative indication of the leukocyte concentration in peritoneal dialysate effluent for the early identification of peritonitis. The reaction at the test strip pad is based on esterase catalyzing the hydrolysis of an indoxyl ester compound to indoxyl. The formed indoxyl reacts with a diazonium salt to produce a violet/purple color, and similar to the Multistix ${ }^{\circledR}$ strip the intensity of the color is correlated with the leukocyte count (Mendler et al., 2010). The Porta $\mathrm{SCC}^{\circledR}$ test is a commercial adaptation of the esterase test specifically designed for detecting SCM in lactating dairy cattle. The Porta $\mathrm{SCC}^{\circledR}$ test utilizes a different dye substrate, 3-(N-tosyl-L-alanyloxy)indol (Taloxin) that is hydrolyzed by esterasein milk to form an intense indigo blue colored dye. We have provided a preliminary report of the test performance of the PortaSCC ${ }^{\circledR}$ test elsewhere (Kandeel et al., 2017) and the focus of this study is to characterize the diagnostic performance of the Multistix ${ }^{\circledR}$ and PeriScreen $^{\text {TM }}$ strips in milk.

Leukocyte esterase reagent strips have been evaluated as a method to diagnose reproductive infections in cattle. Our laboratory evaluated the clinical utility of the Multistix ${ }^{\circledR}$ stripin diagnosing seminal vesiculitis in 155 yearling beef bulls in 2011 (Hiew et al., 2011). A Multistix ${ }^{\circledR}$ strip score of trace or greater had a sensitivity of 0.32 and specificity of 0.93 for detecting the presence of leukocytes in the semen sample. A 2012 study evaluated the clinical utility of the Multistix ${ }^{\circledR}$ stripin diagnosing endometritis in dairy cows at 40-60 days postpartum (Cheong et al., 2012). A Multistix ${ }^{\circledR}$ strip score of moderate or greater had a sensitivity of 0.77 and specificity of 0.52 for detecting the presence of $>10 \%$ neutrophils in cells obtained from uterine lavage fluid samples. Additional studies have been completed evaluating the clinical utility of the Multistix ${ }^{\circledR}$ strip in diagnosing endometritis in dairy cattle (Couto et al., 2013; Hajibemani et al., 2016) and beef cattle (Ricci et al., 2017). Based on the above, we hypothesized that the semi-quantitative estimation of milk esterase activity using two leukocyte esterase reagent strips could provide an economic, rapid, and practical cowside method for diagnosing SCM in lactating dairy cows. Our objective was therefore to characterize the ability of milk esterase activity measured by the Multistix $^{\circledR}$ and PeriScreen ${ }^{\mathrm{TM}}$ strips to predict the presence of SCM and IMI in lactating dairy cattle at dry-off and freshening. These two time periods were selected for investigation because decisions are made at these time points as to whether intramammary antibiotics should be infused in order to treat SCM or IMI.

\section{MATERIALS AND METHODS}

All methods were evaluated and approved by the University of Illinois Institutional Animal Care and Use Committee (IACUC). This study was part of a series of studies evaluating the diagnostic performance of a variety of tests for detecting SCM in lactating dairy cows.

\section{Animals, housing, milking, and feeding}

An observational study using a convenience sample of 115 dairy cows at dry-off, and 92 fresh cows during 4-7 days postpartum), was performed at the University of Illinois Dairy Research Farm (UIDRF) over a period of 13 months between July 1, 2015 and July 31, 2016.

Cows in late lactation were housed outside in a free stall barn. After calving, fresh cows were kept in a closed tie stall barn until they recovered from any postpartum health issues before being moved to a free stall barn. Cows were fed a dry cow ration, an acidogenic total mixed ration in the last 2-3 weeks of gestation, and a lactating cow total mixed ration based on formulations recommended by the National Research Council (NRC, 2001).

Late lactation cows were milked twice daily in a milking parlor at 04:00 and 16:00. Fresh cows were milked three times daily at 05:00, 14:00, 21:30. Data including breed, age, days in milk (DIM), daily milk production, and parity were retrieved from the farm records using the dairy's automatic recording software (PCDart, DRMS, Ames, IA). 


\section{Experimental methods}

The dairy was visited at least once a week to collect foremilk samples from each quarter separately in the same week of drying-off and at 4 to 7 days postpartum. Cows in the free stallbarn were moved to a shaded area and restrained with the aid of a halter. A physical examination was performed on each cow in order to identify the presence of relevant systemic disorders. The teat end of each quarter was cleaned with alcohol $70 \%$ and $20 \mathrm{~mL}$ foremilk samples were collected separately within 50 seconds of first touching any teat using a sterilized plastic tube by hand stripping after discarding the first three squirts of milk.

Five $\mathrm{mL}$ duplicate milk samples for bacteriological examination were then collected aseptically from each quarter into sterile tubes. The teat end was scrubbed with $70 \%$ alcohol soaked cotton swabs until dirt no longer appeared on the swabs. The tube was held at a $45^{\circ}$ angle from the teat end and a mid-stream milk sample was collected aseptically. The milk samples were stored in a cooler with iced water for transportation to the laboratory (National Mastitis Council, 1999) and cultured within $4 \mathrm{~h}$ of milk collection.

The udder and milk were examined by inspection and palpation in order to detect the presence of any abnormalities, including the cardinal signs of inflammation or abnormal milk.

\section{Somatic cell count}

Direct estimation of the SCC was performed electronically using a Delaval cell counter (DCC, DeLaval International AB, Tumba, Sweden). Approximately $1 \mu \mathrm{L}$ of foremilk was drawn into a single-use cassette and inserted into the DCC. The result in cells $/ \mu \mathrm{L}$ of milk was displayed after 45 seconds; this number was multiplied by 1,000 to provide cells/mL of milk.

\section{Esterase activity}

Foremilk esterase activity was measured using two different colorimetric methods (Multistix ${ }^{\circledR}$ and Periscreen ${ }^{\mathrm{TM}}$ strips) within $4 \mathrm{~h}$ of milk collection.

Multistix ${ }^{\circledR} 10$ SG urine test strips (Bayer HealthCare Inc., Elkhart, IN, USA) were used to measure milk esterase activity according to the manufacturer's instructions. The pad contained $0.4 \% \mathrm{w} / \mathrm{w}$ derivatizedpyrrole amino acid ester; $0.2 \% \mathrm{w} / \mathrm{w}$ diazonium salt; $40.9 \%$ w/w buffer; $58.5 \%$ w/w nonreactive ingredients. The stated lower limit of detection in urine was 10-20 leukocytes/ $\mu \mathrm{L}$, equivalent to $10,000-20,000$ leukocytes $/ \mathrm{mL}$. One strip was removed from the bottle and the reagent pads of the strip were completely immersed in a well-mixed milk sample. The strip was removed from the sample within 1 second, gently shaken to remove excess milk, and left to stand on a flat clean surface with the indicator pad facing up for up to 60 minutes. The Multistix ${ }^{\circledR}$ strip reaction was visually scored using the five point chromatic scale provided by the manufacturer as follows; negative, trace, one positive (small), two positive (moderate), three positive (large).The manufacturer recommended that the strip be measured at 2 minutes when used to analyze urine. In preliminary studies we observed that the color of the esterase pad changed slowly over time after immersion in milk, and consequently we visually scored the test strip at 2, 30, and 60 minutes after immersion. Other investigators have determined that a 10 minute reading time was optimal for diagnosing endometritis in dairy cows (Hajibemani et al., 2016).

Serim PeriScreen ${ }^{\circledR}$ test strips were then used to measure milk esterase activity according to the manufacturer's instructions. The developed color in the indicator pad was compared after 4 minutes of immersion in milk with the four point color chart provided by the manufacturer: negative (leukocytes 20-30 cells $/ \mu \mathrm{L}$ in dialysate), trace (leukocytes $\sim 40$ 180 cells $/ \mu \mathrm{L}$ in dialysate), small (leukocytes $\sim 100$ 300 cells $/ \mu \mathrm{L}$ in dialysate), and large (leukocytes > 300 cells $/ \mu \mathrm{L}$ in dialysate). The stated lower limit of detection in peritoneal fluid was therefore 40,000180,000 leukocytes/mL.

\section{Effect of sample temperature}

The effect of sample temperature on the performance of the two esterase reagent strips was investigated using 15 randomly collected $20 \mathrm{~mL}$ composite milk samples obtained from Holstein-Friesian cows during milking in the parlor. The temperatures of the composite milk samples were equilibrated to approximately $4^{\circ} \mathrm{C}, 20^{\circ} \mathrm{C}$, and $37^{\circ} \mathrm{C}$ by placing the samples in the refrigerator, at room temperature, or in a water bath at $37^{\circ} \mathrm{C}$, respectively, for 30 minutes. The two esterase reagent strips were then used to test milk esterase activity as previously described.

\section{Milk culturing for mastitis pathogens}

Milk culturing was performed based on National Mastitis Council recommendations (NMC, 1999) except a $100 \mu \mathrm{L}$ aliquot was used instead of the recommended $10 \mu \mathrm{L}$ aliquot. A pipette and sterile pipette tips were used to aspirate $100 \mu \mathrm{L}$ of each quarter milk sample and the aliquot was placed on one-half of Blood agar (TSA W/ 5\% sheep blood agar; Remel, Lenexa, KS, USA) and MacConkey plates (Remel, Lenexa, KS, USA). The milk sample was then streaked using a sterile wire loop in a fashion that permitted the growth of isolated bacterial colonies. The plates were incubated in an inverted position at $37^{\circ} \mathrm{C}$ for 48 hours and the microbial growth and colony type recorded. The isolated pathogen was identified using colony morphology, hemolysis patterns, biochemical tests including catalase and coagulase test, and Gram staining reaction and cell morphology. Culture results were interpreted by applying published recommendations 
where the isolation of single colony from $0.01 \mathrm{~mL}$ milk, equivalent to the isolation of 10 colonies from $100 \mu \mathrm{L}$ milk, was categorized as an intramammary infection (IMI), (Dohoo et al., 2011).

\section{Statistical analysis}

Data was expressed as median and interquartile range and $\mathrm{P}<0.05$ was considered significant. A statistical software program (SAS 9.4, SAS Inc, Cary NC) was used for all analyses. Subclinical mastitis was defined as SCC was $>200,000$ cell $/ \mathrm{mL}$ using the DCC. Spearman's correlation coefficients (PROC CORR) were calculated to characterize the association between Delaval SCC and milk esterase activity measured by Multistix ${ }^{\circledR}$ and Periscreen ${ }^{\mathrm{TM}}$ strips.

Logistic regression (PROC LOGISTIC) was used to characterize the relationship between SCM as determined by the reference method $(1=\mathrm{SCC}>$ 200,000 cells $/ \mathrm{mL} ; 0=\mathrm{SCC} \leq 200,000$ cells $/ \mathrm{mL}$ ) or IMI as determined by milk culture $(1=>10$ colonies; $0=\langle 10$ colonies) and esterase score measured by the two methods at dry off and freshening. Receiver operating characteristic (ROC) curves were constructed for each logistic regression model. The area under the ROC curve (AUC) was calculated as a global index of test performance; AUC values for ROC curves $>0.9$ typically indicate a highly accurate test, whereas AUC values of 0.7 to 0.9 indicates moderate accuracy, 0.5 to 0.7 low accuracy, and 0.5 represents a chance result (Swets, 1988). Sensitivity and specificity were calculated at the optimal cutpoint of each ROC using the Youden index (the cutpoint where the following expression has its maximum value: $\mathrm{Se}+\mathrm{Sp}-1$ ). This equally weights the value of $\mathrm{Se}$ and $\mathrm{Sp}$. The positive likelihood ratio (+LR) was calculated as: +LR $=\mathrm{Se} /(1-\mathrm{Sp})$; values $>10$ indicate that a positive test is good at ruling in a diagnosis, such as SCM or IMI (Grimes and Schulz, 2005). The Kappa coefficient ( $\kappa$, PROC FREQ) was calculated using the optimal cut-point of the ROC to characterize the level of agreement between milk esterase activity and the two reference methods (SCM, IMI). Values for $\kappa<0.2$ indicate poor agreement, whereas $0.2<\kappa<0.4$ indicates fair agreement, $0.4<\kappa<0.6$ indicates moderate agreement, $0.6<\kappa<0.8$ reflects good agreement, and $\kappa>0.8$ indicates excellent agreement (Landis and Koch, 1977).

The effect of sample temperature on the test result was evaluated using Fisher's exact test (PROC FREQ) for Multistix ${ }^{\circledR}$ and Periscreen ${ }^{\mathrm{TM}}$ strips and mixed models analysis (PROC MIXED) for $\log _{10}(\mathrm{SCC})$ using an unstructured correlation matrix.

\section{RESULTS}

Quarter milk samples $(n=459)$ were obtained at dry off from 115 cattle, comprising 102 HolsteinFriesian, 9 Jersey, 2 Ayrshire, 1 Brown Swiss, and 1
Milking Shorthorn. One cow had a blind quarter. Quarter milk samples $(\mathrm{n}=364)$ were obtained from 92 cattle on day 4 to 7 of lactation, comprising 81 Holstein-Friesian, 8 Jersey, 1 Ayrshire, 1 Brown Swiss, and 1 Milking Shorthorn. Four cows had one blind quarter. The prevalence of SCC based on SCC $>200,000$ cells $/ \mathrm{mL}$ on a quarter basis was $69 \%$ at dry-off and $33 \%$ at freshening. Spearman correlation coefficients between variables of interest at dry-off and freshening are summarized in Table 1.

\section{Multistix ${ }^{\circledR}$ stripscores}

The number of quarters with a trace or higher reaction varied depending on whether the Multistix ${ }^{\circledR}$ strip reaction was visually scored at $2 \mathrm{~min}(0 \%, 0 / 820), 30$ $\min (4 \%, 28 / 669)$, or $60 \min (25 \%, 202 / 799)$. As we were more interested in a higher test sensitivity than a higher test specificity, we analyzed the data using a reading time of $60 \mathrm{~min}$ for the Multistix ${ }^{\circledR}$ stripreaction.

Only two quarters had a Multistix ${ }^{\circledR}$ strip score of large (both at dry off). Consequently, test strip scores of moderate and large were collapsed into a group named moderate/large. The median SCC measured at dry off was 244,500, 529,500, 1,249,000, and $1,818,000$ cell $/ \mathrm{mL}$ in quarters with Multistix ${ }^{\circledR}$ strip scores of negative, trace, small, and moderate/large, respectively (Fig. 1, top panel). For comparison, the median SCC measured at freshening was 100,000, $877,000,4,000,000$, and $4,000,000 \mathrm{cell} / \mathrm{mL}$ in quarters with Multistix ${ }^{\circledR}$ strip scores of negative, trace, small, and moderate/large, respectively (Fig. 1, bottom panel).

The distribution of Multistix ${ }^{\circledR}$ strip scores differed (P $<0.0001)$ for quarters with and without SCM or an IMI (Figs. 1, 2). Higher Multistix ${ }^{\circledR}$ strip scores in a quarter were positively associated with an increased probability of SCM and IMI using a cut-point of $\geq$ trace.

\section{Periscreen ${ }^{\mathrm{TM}}$ stripscores}

Only 2 quarters had a Periscreen ${ }^{\mathrm{TM}}$ strip score of large (one at dry off, one at freshening). Consequently, test strip scores of small and large were collapsed into a group named small/large. The median SCC measured at dry off was 258,500, 953,500 , and $3,664,000$ cell $/ \mathrm{mL}$ in quarters with Periscreen $^{\mathrm{TM}}$ test scores of negative, trace, and small/large, respectively, (Fig. 3, top panel). For comparison, the median SCC measured at freshening was $104,000,901,000$, and $4,000,000$ cell $/ \mathrm{mL}$ in quarters with Periscreen ${ }^{\mathrm{TM}}$ strip scores of negative, trace, and small/large, respectively (Fig. 3, bottom panel).

The distribution of PeriScreen ${ }^{\mathrm{TM}}$ strip scores differed $(\mathrm{P}<0.0001)$ for quarters with and without SCM or an IMI (Figs. 3, 4). Higher PeriScreen ${ }^{\mathrm{TM}}$ strip scores in a quarter were positively associated with an increased 
probability of IMI using a cut-point of $\geq$ trace for the identification of the infected quarters.

\section{Logistic regression analysis}

The AUC, optimal cut-point, Se, Sp, and +LR values identified from logistic regression analysis for diagnosing SCM are presented in Table 2. The AUC for the Multistix ${ }^{\circledR}$ strip at dry off and freshening were similar to that for the PeriScreen ${ }^{\mathrm{TM}}$ strip $(\mathrm{P}=0.87$ and 0.10 , respectively). The $\kappa$ values using the optimal cut-points for SCM for the Multistix ${ }^{\circledR}$ and Peri Screen $^{\mathrm{TM}}$ strips were categorized as fair at dry off and freshening.
The AUC, optimal cut-point, Se, Sp, and +LR values identified from logistic regression analysis for diagnosing IMI are also presented in Table 2. The AUC for the Multistix ${ }^{\circledR}$ strip at dry off and freshening were similar to that PeriScreen ${ }^{\mathrm{TM}}$ strip $(\mathrm{P}=0.97$ and 0.055 , respectively). The $\kappa$ value using the optimal cut-points for SCM were only fair and similar for the Multistix $^{\circledR}$ and Peri Screen ${ }^{\mathrm{TM}}$ strips at dry off and freshening (Table 2).

\section{Effect of milk temperature on test performance} There was no effect of temperature on the SCC $(\mathrm{P}=$ $0.058)$ or the Multistix ${ }^{\circledR}$ and Periscreen ${ }^{\mathrm{TM}}$ strip score $(\mathrm{P}=1.00)$.

Table 1: Spearman correlation coefficients among variables of interest for 115 dairy cows at dry-off and 92 cows at freshening. The information in parentheses are the number of quarters used for comparison and the $\mathrm{P}$ value. $\mathrm{SCC}=$ somatic cell count

\begin{tabular}{|c|c|c|c|}
\hline Variable & Delaval SCC & Multistix ${ }^{\circledR}$ strip & Periscreen $^{\mathrm{TM}}$ strip \\
\hline \multicolumn{4}{|l|}{ Dry off } \\
\hline Delaval SCC & 1.00 & $\begin{array}{c}0.58 \\
(435, \mathrm{P}<0.0001)\end{array}$ & $\begin{array}{c}0.75 \\
(249, \mathrm{P}<0.0001)\end{array}$ \\
\hline Multistix ${ }^{\circledR}$ strip & & 1.00 & $\begin{array}{c}0.60 \\
(242, \mathrm{P}<0.0001)\end{array}$ \\
\hline Periscreen $^{\mathrm{TM}}$ strip & & & 1.00 \\
\hline \multicolumn{4}{|l|}{ Freshening } \\
\hline Delaval SCC & 1.00 & $\begin{array}{c}0.45 \\
(364, \mathrm{P}<0.0001) \\
\end{array}$ & $\begin{array}{c}0.52 \\
(259, \mathrm{P}<0.0001) \\
\end{array}$ \\
\hline Multistix ${ }^{\circledR}$ strip & & 1.00 & $\begin{array}{c}0.75 \\
(259, \mathrm{P}<0.0001) \\
\end{array}$ \\
\hline Periscreen $^{\mathrm{TM}}$ strip & & & 1.00 \\
\hline
\end{tabular}

Table 2: Summary of the results of logistic regression analysis of the ability of milk esterase activity measured by the Multistix ${ }^{\circledR}$ and Periscreen ${ }^{\mathrm{TM}}$ stripsto predict subclinical mastitis (SCM) and intramammary infection (IMI) in quarter milk samples obtained from dairy cows at dry off and freshening.

\begin{tabular}{|c|c|c|c|c|c|c|c|}
\hline & $\mathrm{n}$ & $\begin{array}{l}\text { Optimal strip cut-point } \\
\text { for esterase activity }\end{array}$ & AUC & Sensitivity & Specificity & $+\mathrm{LR}$ & $\kappa$ \\
\hline \multicolumn{8}{|l|}{ Subclinical mastitis } \\
\hline \multicolumn{8}{|l|}{ Dry off } \\
\hline Multistix ${ }^{\circledR}$ strip & 435 & $\geq$ trace & 0.71 & 0.50 & 0.88 & 4.2 & 0.31 \\
\hline Periscreen $^{\mathrm{TM}}$ strip & 249 & $\geq$ trace & 0.75 & 0.51 & 0.98 & 25.5 & 0.32 \\
\hline \multicolumn{8}{|l|}{ Freshening } \\
\hline Multistix ${ }^{\circledR}$ strip & 364 & $\geq$ trace & 0.63 & 0.28 & 0.98 & 14 & 0.18 \\
\hline Periscreen ${ }^{\mathrm{TM}}$ strip & 364 & $\geq$ trace & 0.66 & 0.32 & 1.00 & $\infty$ & 0.22 \\
\hline \multicolumn{8}{|c|}{ Intramammary infection } \\
\hline \multicolumn{8}{|c|}{ Dry off } \\
\hline Multistix ${ }^{\circledR}$ strip & 435 & $\geq$ trace & 0.60 & 0.52 & 0.64 & 2.1 & 0.10 \\
\hline Periscreen $^{\mathrm{TM}}$ strip & 249 & $\geq$ trace & 0.66 & 0.66 & 0.66 & 1.9 & 0.19 \\
\hline \multicolumn{8}{|l|}{ Freshening } \\
\hline Multistix ${ }^{\circledR}$ strip & 364 & $\geq$ trace & 0.65 & 0.36 & 0.94 & 6.0 & 0.34 \\
\hline Periscreen $^{\mathrm{TM}}$ strip & 364 & $\geq$ trace & 0.75 & 0.54 & 0.94 & 9.0 & 0.48 \\
\hline
\end{tabular}

$\mathrm{n}=$ number of quarters used in the analysis; AUC - area under the response characteristic curve; $\kappa=$ kappa coefficient, which is a measure of agreement between the prediction of SCM or IMI using an increased esterase activity of trace or higher measured by the two methods and a diagnosis by the reference method; $+\mathrm{LR}=$ positive likelihood ratio. 

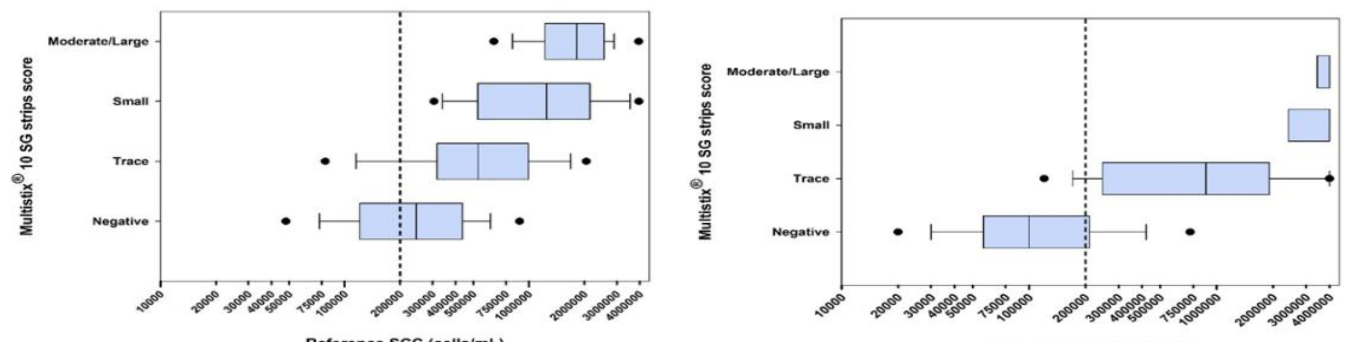

Figure 1: Top panel - Box and whiskers plot of the association between the Multistix ${ }^{\circledR}$ strip scores and somatic cell count (SCC) measured by the reference method in 435 quarters at dry off. The shaded box represents the first and third quartile, the vertical line in the shaded box represents the median value, the whiskers represent the $10^{\text {th }}$ and $90^{\text {th }}$ percentiles, and filled circles represent data points outside this percentile range. The vertical dashed black line indicates the SCC cut-point for subclinical mastitis $(200,000$ cells $/ \mathrm{mL})$.

Bottom panel - Box and whiskers plot of the association between the Multistix ${ }^{\circledR}$ strip scores and SCC measured by the reference method in 364 quarters at freshening.
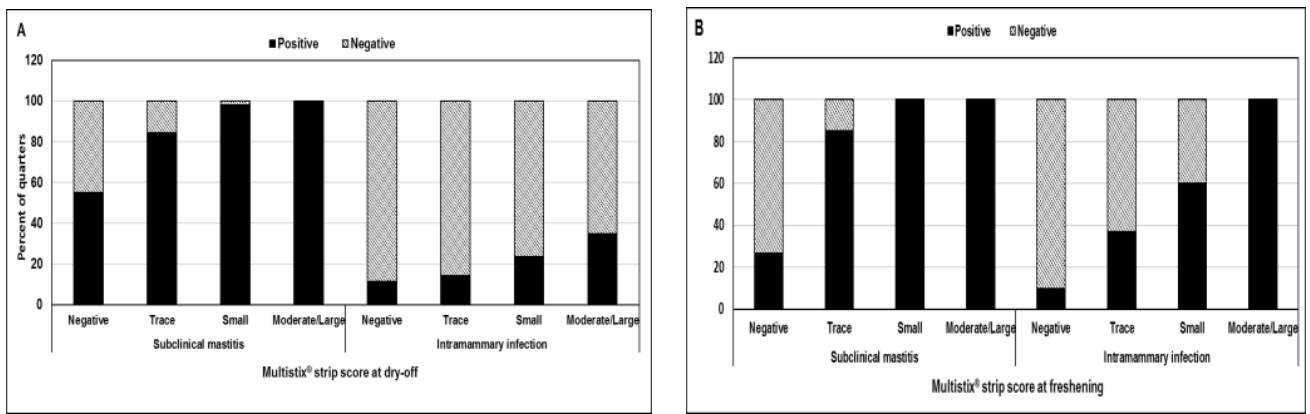

Figure 2: Panel A - Associations between Multistix ${ }^{\circledR}$ strip scores and the presence of subclinical mastitis (SCM) or an intramammary infection (IMI) for 435 quarters at dry-off.

Panel B - Associations between Multistix ${ }^{\circledR}$ strip scores and the presence of SCM or IMI for 364 quarters at freshening.
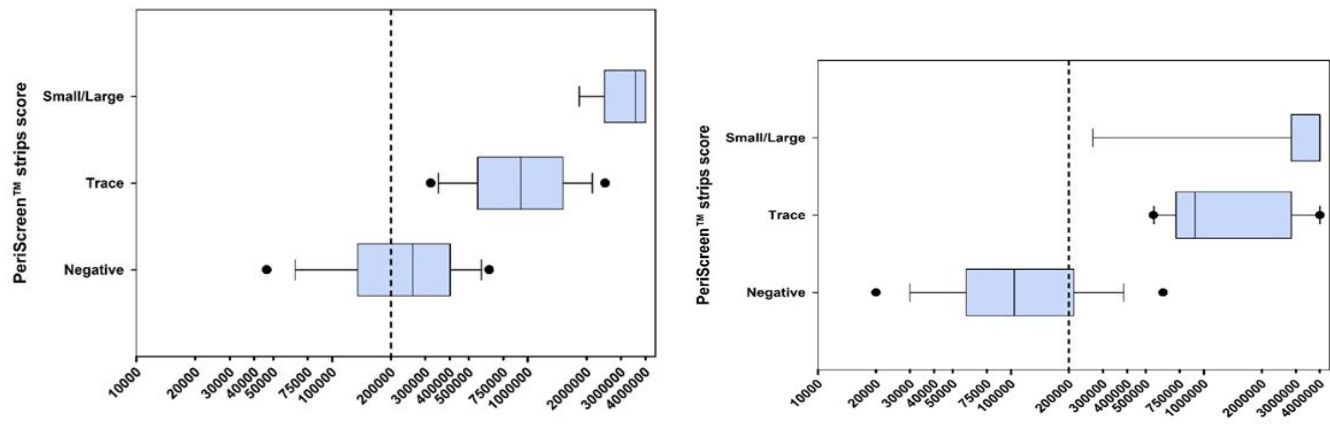

Reference SCC (cells $/ \mathrm{mL}$ )

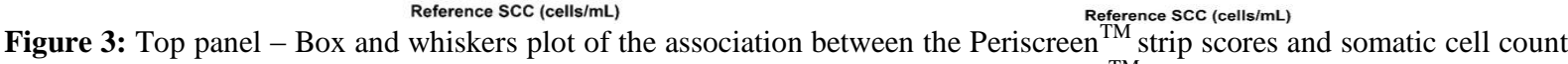
(SCC) measured by the reference method in 249 quarters at dry off. The Periscreen ${ }^{\mathrm{TM}}$ strip scores were categorized as negative, trace, or small/large. See Fig. 1 legend for more details.

Bottom panel - Box and whiskers plot of the association between the Periscreen ${ }^{\mathrm{TM}}$ strip scores and SCC measured by the reference method in 259 quarters at freshening.
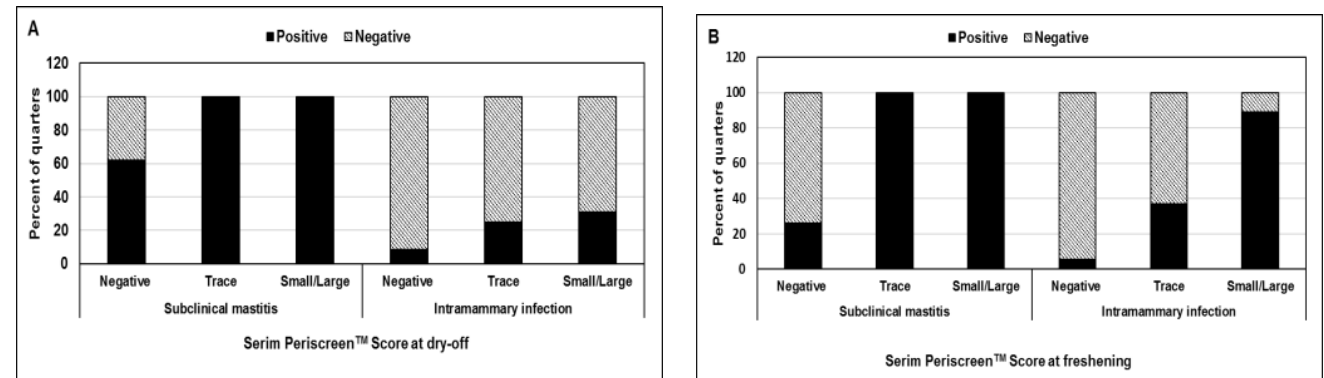

Figure 4: Top panel - Associations between the Periscreen $^{\mathrm{TM}}$ score and the presence of subclinical mastitis (SCM) or an intramammary infection (IMI) for 249 quarters at dry-.

Bottom panel - Associations between the Periscreen ${ }^{\mathrm{TM}}$ score and the presence of SCM or an IMI for 259 quarters at freshening 


\section{DISCUSSION}

This appears to be the first study evaluating the clinical performance of Multistix ${ }^{\circledR}$ and Peri Screen ${ }^{\mathrm{TM}}$ strips for identifying SCM in dairy cattle at dry-off and early lactation based on the semi-quantitative measurement of leukocyte esterase activity in milk. The major findings of our study were that the clinical utility of the Multistix ${ }^{\circledR}$ and PeriScreen ${ }^{\mathrm{TM}}$ strips for diagnosing SCM was only fair as clinically useful tests typically have an AUC $>0.80$ and $\kappa>0.6$. We therefore conclude that the Multistix ${ }^{\circledR}$ and PeriScreen $^{\mathrm{TM}}$ stripsdo not provide clinically useful cow-side tests for diagnosing SCM in lactating dairy cattle.

Milk esterase activity was extensively studied in the 1960's as a possible diagnostic method for SCM. Several studies reported a rapid increase in milk esterase activity either parallel with or immediately after an increase in milk SCC (Forster et al., 1961; Booth et al., 1965; Marquardt and Forster, 1965; Marquardt et al., 1966). In the initial study, Forster and colleagues recommended the development of simple colorimetric procedure to assay esterase, since phenol is a hydrolytic product of the substrate, phenyl acetate (Foster et al., 1961); however, the procedure used to measure esterase activity at that time was a manometric system involving the Warburg apparatus (Warburg manometric techniques) that was timeconsuming and required trained personnel and expensive equipment (Luedecke et al., 1967). Consequently, measuring esterase as a mastitis diagnostic tool lost favor and by 1968 , milk esterase activity was believed to offer little practical diagnostic benefit over the milk leukocyte count (Prasad, and Newbould, 1968).

Our results are similar to that previously reported (Forster et al., 1961; Booth et al., 1965; Marquardt, and Forster, 1965; Marquardt et al., 1966) in that a higher milk esterase activity is associated with an increased probability of SCM, as determined by SCC $>200,000$ cells $/ \mathrm{mL}$. This finding was expected on the assumption that milk esterase activity is correlated with milk leukocyte count, as increased milk SCC reflects a marked increase in milk leukocyte count (Kitchen, 1981; Pyörälä, 2003; Constable et al., 2016). However, the exact source of esterase in cow's milk has not been confirmed (Marquardt et al., 1966; Prasad and Newbould, 1968), and approximately $70 \%$ of the esterase activity in cow's milk is due to nonenzyme proteins, with only $20 \%$ of the activity being enzymatic in origin (Downey and Andrews, 1965). Because esterase activity in plasma is typically 1,000 to 2,000 times the activity in milk (Marquardt and Forster, 1965), it is possible that some of the milk esterase activity is due to increased blood-milk permeability and movement of plasma constituents into the mammary gland and secretions (Marquardt et al., 1966), or the intrinsic properties of non- enzymatic proteins for hydrolysis (Downey and Andrews, 1965).

The lack of agreement between milk esterase activity and the presence of IMI based on culture results may be attributed to the failure to isolate mastitis pathogen from the majority of quarter milk samples with elevated SCC. The latter situation may result from mastitis episodes where bacteriais not the cause of udder inflammation, intermittent shedding or low concentration of the mastitis pathogen from the infected gland, intracellular location of the pathogens and the presence of bacterial growth inhibitors in milk, or the spontaneous elimination of the infection from the udder (Constable et al., 2016). Furthermore, culture negative quarter samples with increased SCC may reflect delayed healing of infection where the pathogens are eliminated from the udder while the infiltration of leukocytes continues until complete healing has occurred.

The performance of the esterase reagent strips in milk is likely to have been impacted by matrix effects, where the high protein and fat content of milk relative to urine may have contributed to their suboptimal performance. The strips and color scales were developed for the diagnosis of infection in the urine, where the protein concentration is usually lower than $1 \mathrm{~g} / \mathrm{L}$, and in ascites, where the protein concentrations is less than $30 \mathrm{~g} / \mathrm{L}$ but fat is not present. For comparison, milk is a complex physicochemical suspension; with the bulk tank milk for this dairy herd averaging $32 \mathrm{~g} / \mathrm{L}$ of protein and $36 \mathrm{~g} / \mathrm{L}$ of fat. Protein could decrease leukocyte esterase activity, either by the presence of an inhibitor of this enzyme, or by physical interference with the reagent pad detergent or enzyme substrate (Gülberg et al., 2007; Nousbaum et al., 2007). The protein concentration may also provide a possible explanation for the slightly better performance of PeriScreen ${ }^{\mathrm{TM}}$ strip sover the Multistix $^{\circledR}$ strips, where the PeriScreen ${ }^{\mathrm{TM}}$ strips were developed to be used in patients with ascites where the protein content is $\approx 30 \mathrm{~g} / \mathrm{L}$ and closer to that of milk $(\approx 36 \mathrm{~g} / \mathrm{L})$ than urine $(1 \mathrm{~g} / \mathrm{L})$. Milk fat may also have interfered with the reaction of the strip through physical interference with the detergent in the reagent pad.

The costs of the three tests used in this study were US $\$ 0.36, \$ 4.00$, and $\$ 2.33$ for the Multistix ${ }^{\circledR}$ strips, PeriScreen $^{\text {TM }}$ strips, and DCC test respectively, although the DCC test cost does not include the purchase cost of the analyzer. For comparison, the California Mastitis Test (CMT) costs \$0.04/test. Because of its cow-side application, much lower cost, and acceptable sensitivity and specificity values in this study population, there does not appear to be a persuasive reason for preferring the Multistix ${ }^{\circledR}$ or PeriScreen $^{\mathrm{TM}}{ }^{\mathrm{T}}$ strips over the CMT.

Aprimary goal of our laboratory is to find a rapid, accurate on-farmor cow-side test for identifying 
quarters with SCM or IMI. We considered that sensitivity and specificity of the tests under evaluation were equally important. On this basis, AUC, $\kappa$, and +LRare useful indices for the overall performance of a clinical test. Ideally, such a test should have an AUC>0.90, a sensitivity close to $100 \%$, specificity as high as possible, and +LR $>10$. Using the optimal cut-points identified during logistic regression, the AUC for both Multistix ${ }^{\circledR}$ and PeriScreen $^{\mathrm{TM}}$ strips indicated low to moderate accuracy at freshening and dry-off, respectively. Similarly, the $\kappa$ coefficient indicated fair agreement between both the Multistix ${ }^{\circledR}$ and Peri Screen ${ }^{\text {TM }}$ strips result and the reference method at both freshening and dry-off in classifying quarters by infection status. Although the $+\mathrm{LR}$ was $>10$ for diagnosing SCM using the Multistix ${ }^{\circledR}$ strip at freshening and the Peri Screen $^{\mathrm{TM}}$ strip at dry off and freshening, the sensitivity of the two strips was too low to make them useful. Our findings therefore indicate an overall suboptimal performance of both esterase reagent strips in milk. Consequently, neither strip appears to provide a clinically useful test for identifying quarters with SCM at dry off or freshening.

\section{CONFLICT OF INTEREST}

There are no conflicts of interest to declare.

\section{DISCLOSURE}

This work was supported, in part, by the Cultural and Educational Bureau, Embassy of the Arab Republic of Egypt. This report represents a portion of the thesis submitted by the first author to the graduate school of Benha University as partial fulfillment of the requirement for the $\mathrm{PhD}$ degree.

\section{REFERENCES}

Booth, R.A.; Morse, G.E. and Treece, J.M. (1965): Relationship of A-esterase activity, blood serum albumin, and leucocyte count during experimental exposure to Streptococcus agalactia (Cornell Strain 48). Journal of Dairy Science, 48:822.

Cheong, S.H.; Nydam, D.V.; Galvao, K.N.; Crosier, B.M.; Ricci, A.; Caixeta, L.S.; Sper, R.B.; Fraga, M.; and Gilbert, R.O. (2012):Use of reagent test strips for diagnosis of endometritis in dairy cows. Theriogenology. 77:858-864.

Constable, P.D.; Hinchcliff, K.W.; Done, S.H. and Gruenberg, W. (2016): Veterinary Medicine: A textbook of the diseases of cattle, horses, sheep, pigs and goats. Chapter 20, Mastitis. Elsevier Health Sciences. 2113-2208.

Couto, G.B.; Vaillancourt, D.H. and Lefebvre, R.C. (2013): Comparison of a leukocyte esterase test with endometrial cytology for diagnosis of subclinical endometritis in postpartum dairy cows. Theriogenology. 79:103-107.

Dohoo, I.R.; Smith, J.; Andersen, S.; Kelton, D.F. and Godden, S. (2011): Diagnosing intramammary infections: Evaluation of definitions based on a single milk sample. Journal of Dairy Science.94:250-261.

Downey, W.K. and Andrews, P. (1965): Esterase activity of the non-enzymic proteins of milk and serum. Biochemical Journal, 96:21c-23c.

Forster, T.L.; Montgomery, M.W. and Montoure, J.E. (1961): Some factors influencing the activity of the A-, B-, and C- esterases of bovine milk. Journal of Dairy Science.44: 1420.

Grimes, D.A. and Schulz, K.F. (2005): Refining clinical diagnosis with likelihood ratios. The Lancet, 365(9469):1500-1505.

Gülberg, V.; Gerbes, A.L.; Sauerbruch, T. and Appenrodt, B. (2007): Insufficient sensitivity of reagent strips for spontaneous bacterial peritonitis. Hepatology.46:1669-1670.

Hajibemani, A.; Mirzaei, A.; Sharifiyazdi, H. and Ghasrodashti, A.R. (2016): Vaginal fornix discharge cellularity and its leukocyte esterase activity for diagnosis of endometritis in dairy cows. İstanbul Üniversitesi Veteriner Fakültesi Dergisi. 42:57-64.

Hiew, M.W.H.; Horstman, L.A.; Singleton, W.L.; Messick, J.B. and Constable, P.D. (2011): Evaluation of 2 chute-side tests for the detection of leukocytes and bacteria in semen from yearling bulls. AABP conference, $44^{\text {th }}$ Annual Conference St Louis, MO, September 2011.

Jacobs, J.A.; De Brauwer, E.I.; Cornelissen, E.I. and Drent, M. (2000): Correlation of leukocyte esterase detection by reagent strips and the presence of neutrophils: a study in BAL fluid. Chest Journal 118:1450-1454.

Kandeel, S.A.; Megahed, A.A. and Constable, P.D. (2017): Comparison of six on-farm tests to estimate somatic cell count at dry-off in dairy cattle. Proceedings of the $27^{\text {th }}$ American College of Veterinary Internal Medicine (ACVIM), Gaylord National Harbor Resort and Convention Center National Harbor, MD, USA, p. 134.

Kitchen, B. (1981): Review of the progress of dairy science: Bovine mastitis: Milk compositional changes and related diagnostic tests. Journal of Dairy Research. 48:167-188.

Koulaouzidis, A.; Leontiadis, G.I.; Abdullah, M.; Moschos, J.; Gasem, J.; Tharakan, J.; Maltezos, E. and Saeed, A.A. (2008): Leucocyte esterase reagent strips for the diagnosis of spontaneous bacterial peritonitis: a systematic review. European Journal of Gastroenterology and Hepatology, 20:10551060 .

Kutter, D.; Figueiredo, G. and Klemmer, L. (1987): Chemical detection of leukocytes in urine by 
means of a new multiple test strip. Journal of Clinical Chemistry and Clinical Biochemistry. 25:91-94.

Landis, J.R. and Koch, G.G. (1977): The measurement of observer agreement for categorical data. Biometrics 33:159-174.

Luedecke, L.O.; Forster, T.L. and Ashworth, U.S. (1967): Relationship between California Mastitis Test reaction and leucocyte count, catalase activity, and A-esterase activity of milk from opposite quarters. Journal of Dairy Science. 50 (10):1592-1596.

Marquardt, R.R. and Foster, T.L. (1965): Titrimetric procedure for assay of milk arylesterase activity. Journal of Dairy Science. 48: 16021606.

Marquardt, R.R.; Forster, T.L.; Spencer, G.R. and Stabenfeldt, G.H. (1966): A-esterase activities of milk from cows with experimentally induced mastitis. Journal of Dairy Science. 49:631-635.

McNabb, D.C.; Dennis, D.A.; Kim, R.H.; Miner, T.M.; Yang, C.C. and Jennings, J.M. (2017): Determining false positive rates of leukocyte esterase reagent strip when used as a detection tool for joint infection. The Journal of Arthroplasty, 32: 220-222.

Mendler, M.H.; Agarwal, A.; Trimzi, M.; Madrigal, E.; Tsushima, M.; Joo, E.; Santiago, M.; Flores, E.; David, G.; Workman, A. and Runyon, B. (2010): A new highly sensitive point of care screen for spontaneous bacterial peritonitis using the leukocyte esterase method. Journal of Hepatology 53: 477-483.

Moosa, A.A.; Quortum, H.A. and Ibrahim, M.D. (1995): Rapid diagnosis of bacterial meningitis with reagent strips. Lancet. 345: 1290-1291.

National Mastitis Council (NMC) (1999): Microbiological Procedures for the Diagnosis of Bovine Udder Infection. National Mastitis Council.3rd ed. Arlington, Virginia, USA.

National Research Council (NRC) (2001): Nutrient Requirements of Dairy Cattle, 7th revised version, ed. Natl AcadSci, Washington, DC, USA.

Nousbaum, J.B.; Cadranel, J.F.; Nahon, P.; Khac E.N.; Moreau, R.; Thévenot, T.; Silvain, C.; Bureau, C.; $\quad$ Nouel, O.; $\quad$ Pilette, C.; Paupard, T.; Vanbiervliet, G.; Oberti, F.;
Davion, T.; $\quad$ Jouannaud, V.; $\quad$ Roche, B.; Bernard, P.H.; $\quad$ Beaulieu, S.; $\quad$ Danne, O.; Thabut, D.; $\quad$ Chagneau-Derrode, C.; $\quad$ de Lédinghen, V.; Mathurin, P.; Pauwels, A.; Bronowicki, J.P.; $\quad$ Habersetzer, F.; Abergel, A.; Audigier, J.C.; Sapey, T.; Grangé, J.D. and Tran, A. (2007): Diagnostic accuracy of the Multistix8 SG reagent strip in diagnosis of spontaneous bacterial peritonitis. Hepatology. 45:1275-1281.

Prasad, L.B.M. and Newbould, F.H.S. (1968): Arylesteraseactivity of milk from normal and experimentally infected bovine mammary glands. Canadian Veterinary Journal. 9:230236.

Pyörälä, S. (2003): Indicators of inflammation in the diagnosis of mastitis. Veterinary Research. 34: 565-578.

Ricci, A.; Bonizzi, G.; Sarasso, G.; Gallo, S.; Dondo, A.; Zoppi, S. and Vincenti, L. (2017): Subclinical endometritis in beef cattle in early and late postpartum: Cytology, bacteriology, haptoglobin and test strip efficiency to evaluate the evolution of the disease. Theriogenology 94: 86-93.

St. John, A.; Boyd, J.C.; Lowes, A.J. and Price, C.P. (2006): The use of urinary dipstick tests to exclude urinary tract infection: a systematic review of the literature. American Journal of Clinical Pathology, 126:428-436.

Swets, J.A. (1988): Measuring the accuracy of diagnostic systems. Science. 240:1285-1293.

Urdea, M.; $\quad$ Penny, L.A.; Olmsted, S.S.; Giovanni, M.Y.; Kaspar, P.; Shepherd, A.; Wilson, P.; $\quad$ Dahl, C.A.; $\quad$ Buchsbaum, S.; Moeller, G. and Hay Burgess, D.C. (2006): Requirements for high impact diagnostics in the developing world. Nature.1:73-9.

Viguier, C.; Arora, S.; Gilmartin, N.; Welbeck, K. and O'Kennedy, R. (2009): Mastitis detection: current trends and future perspectives. Trends in Biotechnology. 27:486-493.

Yetisen, A.K.; Akram, M.S. and Lowe, C.R. (2013): Paper based microfluidic point-of-care diagnostic devices. Lab on a Chip. 13: 2210 2251.

Zhao, X. and Lacasse, P. (2008): Mammary tissue damage during bovine mastitis: causes and control. Journal of Animal Science. 86(13suppl): 57-65. 


\section{الفائدة الاكلينيكية لاثنين من الاشرطة الكاشفة عن انزيم الاستيريز المتحرر من الكريات البيضاء

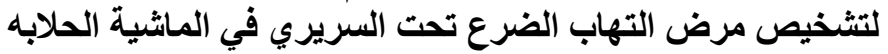

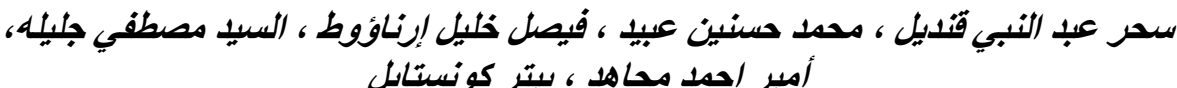 \\ E-mail: skandeel@illinois.edu \\ Assiut University web-site: www.aun.edu.eg}

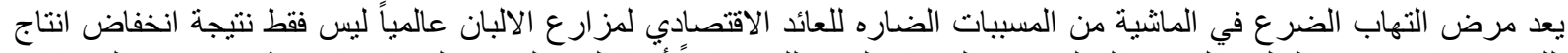

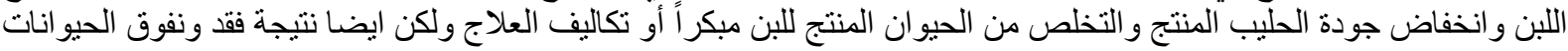

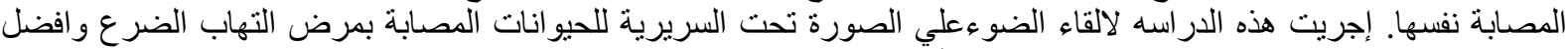

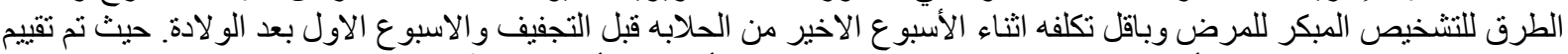

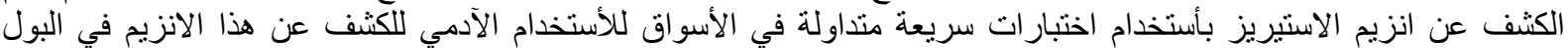

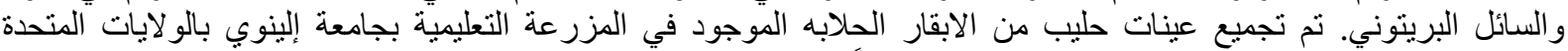

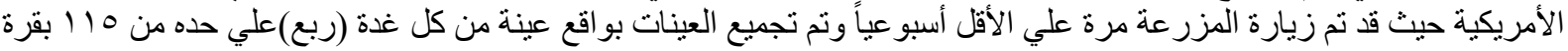

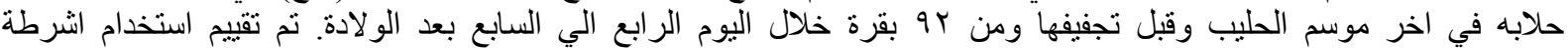

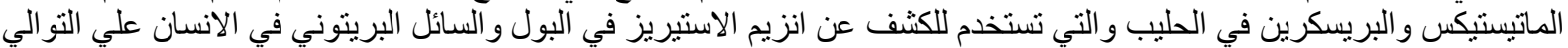

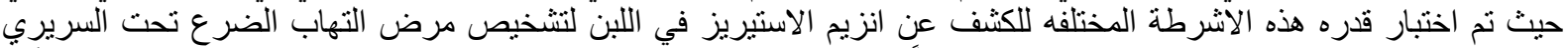

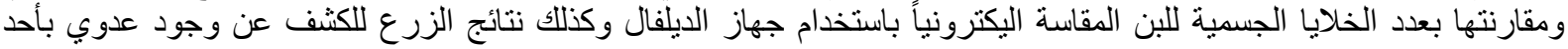

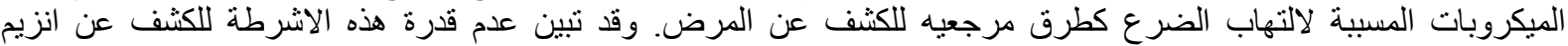

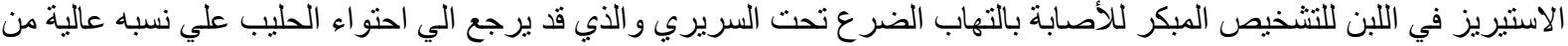

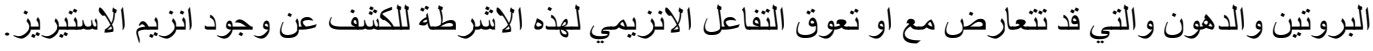

